\title{
WPS4111
}

\section{Social Health Insurance Reexamined}

\author{
by \\ Adam Wagstaff ${ }^{a}$ \\ ${ }^{a}$ Development Research Group, The World Bank, Washington DC, USA
}

\begin{abstract}
Social health insurance $(\mathrm{SHI})$ is enjoying something of a revival in parts of the developing world at the moment. Many countries that have in the past relied largely on tax finance (and out-of-pocket payments) have introduced SHI, or are thinking about doing so. And countries with SHI already in place are making vigorous efforts to extend coverage to the informal sector. Ironically, this revival is occurring at a time when the traditional SHI countries in Europe have either already reduced payroll financing in favor of general revenues, or are in the process of doing so. This paper examines how SHI fares in health care delivery, revenue collection, covering the formal sector, and its impacts on the labor market. It argues that SHI does not necessarily deliver good quality care at a low cost, partly because of poor regulation of SHI purchasers. It suggests that the costs of collecting revenues can be substantial, even in the formal sector where nonenrollment and evasion are commonplace, and that while SHI can cover the formal sector and the poor relatively easily, it fares badly in terms of covering the nonpoor informal sector workers until the economy has reached a high level of economic development. The paper also argues that SHI can have negative labor market effects, including formal sector workers moving into the informal sector, and poor households covered at the taxpayer's expense being caught in a poverty trap.
\end{abstract}

Contact author: Adam Wagstaff, World Bank, 1818 H Street NW, Washington, D.C. 20433, USA. Tel. (202) 4730566. Fax (202)-522 1153. Email: awagstaff@worldbank.org.

Keywords: social health insurance; health financing.

Acknowledgements: Without wishing to incriminate them in any way, I should like to thank Jan Bultman, Pablo Gottret, Matthew J owett and Magnus Lindelow for helpful comments on an earlier version of this paper. The findings, interpretations and conclusions expressed in this paper are entirely those of the author, and do not necessarily represent the views of the World Bank, its Executive Directors, or the countries they represent.

World Bank Policy Research Working Paper 4111, January 2007

The Policy Research Working Paper Series disseminates the findings of work in progress to encourage the exchange of ideas about development issues. An objective of the series is to get the findings out quickly, even if the presentations are less than fully polished. The papers carry the names of the authors and should be cited accordingly. The findings, interpretations, and conclusions expressed in this paper are entirely those of the authors. They do not necessarily represent the view of the World Bank, its Executive Directors, or the countries they represent. Policy Research Working Papers are available online at http://econ.worldbank.org. 


\section{Introduction}

Social health insurance (SHI) is enjoying something of a revival in parts of the developing world. ${ }^{1}$ Many countries that have in the past relied largely on tax finance (and out-ofpocket payments) have introduced SHI, or are thinking about doing so. ${ }^{2}$ And countries with SHI already in place are making vigorous efforts to extend coverage to the informal sector. ${ }^{3}$ Ironically, this revival is occurring at a time when three of the oldest SHI countries-France, Germany and the Netherlands-are all in the process of reducing their reliance on payroll contributions. ${ }^{4}$ This seems an opportune moment to reexamine the merits of SHI as a health financing mechanism.

\section{SHI and health care delivery}

One argument made in favor of SHI over tax financing is that the latter is inextricably linked to a model of health care delivery that produces poor quality care at an unnecessarily high cost. Typically, this entails a ministry of health $(\mathrm{MOH})$ delivering health care through its own network of facilities, which are paid through a mixture of budgets and salaries, and whose degree of autonomy is severely limited. SHI offers, it is argued, the prospect of wresting at least some control of the delivery of health care out of the hands of the health ministry, either through a

\footnotetext{
${ }^{1}$ Two recent conferences, both cohosted by the German government's aid agency, focused on SHI in developing and transition economies, one in Berlin in November 2005, the other in Manila in October 2006. Details are to be found at http://www.shiconference.de/ and http://www.shiconferencemanila.info/.

${ }^{2}$ Examples include Vietnam (1993), Nigeria (1997), Tanzania (2001) and Ghana (2005). Discussions are underway in South Africa, Zimbabwe, Cambodia and Laos. Malaysia also recently began debating a shift to SHI.

${ }^{3}$ Examples include Colombia, Mexico, the Philippines, and Vietnam.

${ }^{4}$ France widened the tax base from earnings to include nonwage income. Germany as discussed below is contemplating reducing the emphasis on the payroll, while The Netherlands in 2005 introduced a reform where insurers receive only half their income from payroll revenues (albeit channeled through a central fund), the rest coming from flat-rate direct contributions from members (with offsetting income supplements for low income groups) (Gottret and Schieber 2006; International Network on Health Policy \& Reform 2006). In addition, to these changes, it is worth noting that Iceland and Spain both shifted wholesale from SHI to taxfinance in the late 1980s.
} 
dedicated SHI delivery system, as in some Latin American countries, or by forcing an institutional separation of the 'purchasing' of health care, which would be done by insurers or the a SHI agency, and the delivery of health care, which could remain the responsibility of the health ministry’s job, as in, say, Vietnam, or could be contracted out to the private sector, as in, say, Argentina.

There is actually no evidence showing that in Europe SHI countries enjoy better quality health care than countries with tax-financed health systems. For example, survival rates of cancer patients are relatively poor in Denmark and England, but good in Iceland and Sweden, which also operate tax-financed systems; the latter two, in fact, have better survival rates than France, Germany and the Netherlands, which all operate SHI financing systems (Micheli et al. 2003). In any case, other system variables are likely to matter too; the bivariate associations point, for example, to survival prospects for cancer patients in Europe being better in richer countries, and in countries that spend more on health care. In Latin America, where dedicated SHI facilities or private providers deliver care to SHI members and health ministry facilities deliver care to the rest of the population, both types of provider have been criticized for delivery poor quality care. SHI providers, for example, have acquired a reputation for "focusing a disproportionate amount of resources on high technology and curative care to the near total exclusion of primary health care” (Fiedler 1996). But public providers have been argued to be unresponsive and inconvenient, and, especially at lower levels, to deliver poor quality care (cf. e.g. Lewis, Eskeland and Traa-Valerezo 2004).

As far as cost is concerned (or at least health care spending as a share of GDP), what emerges from the OECD evidence is that it is not so much the source of revenues that matters but rather the characteristics of the delivery system: the role of the public sector in health care 
provision, how providers are paid, whether a primary care gatekeeper exists, and so on (Docteur and Oxley 2003). It is increasingly the case that there is no one-to-one correspondence between these characteristics and the way revenues are raised: tax finance and social insurance are simply different ways of raising revenues (cf. Jonsson and Musgrove 1997). Each can be coupled with an integrated delivery system: in Britain's prereformed tax-financed system, there used to be no distinction between purchasers and providers, which were directly-managed units under the health ministry; in Mexico's SHI system, there are two public integrated systems standing side by side, the health ministry's and the social security institute's. But each financing system can equally well be coupled with a contract delivery system: Argentina's SHI system contracts the delivery of care out to private providers, as happens in the Dutch system; in Canada's taxfinanced system care is delivered by nonprofit private providers; in the new British system increasingly autonomous public providers (and some private ones) deliver care under contract to public purchasers; and in the tax-financed systems of Cambodia (Bhushan, Keller and Schwartz 2002) and Uganda (Reinikka and Svensson 2003), some health services are delivered under contract by nongovernmental organizations.

The purchaser-provider split approach, at least on paper, has much to commend it compared to an integrated system. It holds the promise of a purchaser developing a strong information system covering costs, quality and health needs, which can be used to steer resources to where they are needed most and will have the biggest impact. There may be political economy reasons why such a purchaser-provider split is hard to engineer in a tax-financed system and why it is hard to grant public providers the necessary autonomy to be able to respond to the incentives a purchaser-provider split generates, such as civil service regulations, treasury rules on investments, etc. Setting up SHI scheme may be a way to bring such changes about. But is it the only one? And is it the best? 
One relevant question in this regard is whether SHI purchasers do better than those in tax-financed systems in terms of costs and quality by virtue of being more accountable to the public. It is indeed possible that a contributory system could result in a public that is more inclined to ask questions when the quality of care fails to meet its expectations, while the public in a tax-financed system can never point to specific taxes that were used to finance the health system. In practice, it is far from clear that SHI purchasers are more accountable to their members. On the face of it, the Philippines SHI agency, known as PhilHealth, has good governance arrangements. Yet it has successfully resisted calls to use its surplus to finance a more generous benefit package, and there have been claims that politicians have sought to use it to influence the outcomes of elections by appointing allies to jobs within the agency and having them allocate free insurance cards to marginal voters. A World Bank report in the late 1990s on health insurance in Argentina (World Bank 1997), commenting on the purchasing capacity of health insurers, argued that "it is acknowledged by Argentines that personal connections and corrupt practices, instead of quality and economy, weigh heavily in the award of capitated contracts and other payments to medical providers and suppliers, and this adds substantially to the inefficiency and high cost of health care in Argentina” (p.7). The World Bank recommended stronger regulation of health insurers and competition between them. Corruption in SHI agencies on an even bigger scale has recently been highlighted in Armenia, Kazakhstan, and Kenya (Gottret and Schieber 2006).

A likely common problem in these situations is that contributions do not automatically translate into accountability. By contrast, in a tax system, the electorate typically has the chance to express its views about the way the government has spent its taxes through the ballot box. One way that accountability can be enhanced in a SHI system is by letting members vote with their feet-i.e. giving them the option of choosing their insurer. Germany has discussed this 
extensively, and the recent reforms in the Netherlands provided for such competition. Time will tell whether the competitive approach to SHI yields the hoped-for benefits. There are, of course, potential drawbacks, including the loss of monopsony power, the scope for cream-skimming, and the risk that insurers will neglect preventive activities (by the time the benefits accrue the individual in question may be with another insurer) (Kenkel 2000). ${ }^{5}$ Certainly in some SHI countries, the trend seems to be not just away from competition among insurers but away from fragmentation. In Austria, where weak purchasing capacity has also been identified as a problem, it has been proposed to reduce the power of sickness funds in purchasing decisions and instead to create government health purchasing agencies on the state and federal levels, the aim being "to optimize resource utilization, enhance integration of service delivery and pool financial resources to improve purchasing” (International Network on Health Policy \& Reform 2006). Slovenia and the Kyrgyz Republic are examples of SHI countries that have opted for the single-payer model. In such a setting, methods other than having SHI enrollees voting with their feet are required to promote accountability.

\section{SHI offers larger and more predictable revenues for health care}

Another argument made in favor of SHI is that tax revenues are typically insufficient to finance enough health care at a quality level that meets the expectations of the population. SHI, it is argued, offers the prospect of larger revenues for systems considering a complete switch to SHI, or supplementary revenues for those moving towards a mixed financing system where additional tax revenues for some reason cannot be raised. Some also see SHI as a way to get round what they see as the inherent unpredictability of tax finance: tax revenues, it is argued, rise

\footnotetext{
${ }^{5}$ This is why breast cancer and other screening programs in the Netherlands are paid directly to implementing institutions although they are financed out of from SHI contributions and direct subsidies from the central fund.
} 
and fall in line with the economy, and the health ministry's share of tax revenues is vulnerable to negotiations within the government.

The most obvious point to make here is that the only immediate 'tax base' for SHI are the earnings of those in formal sector, so that if indeed the aim is to cover the entire population, there would need to be a very high contribution rate and hence a substantial subsidy from formal sector workers to informal sector workers and others. The challenge of how to enroll and raise revenues from the informal sector is addressed in a moment; suffice to say for now that the task is a huge one, that the revenues raised are rarely those that would be expected on the basis of contribution rules, and the collection costs are formidable.

It turns out that these concerns are also pressing ones in the context of the formal sector. It is sometimes argued that people's willingness to make SHI contributions is likely to be higher than their willingness to pay taxes: they can link their contribution to an entitlement; and they may be willing to contribute more in respect of others if they are asked to display 'solidarity' with fellow workers in a specific industry or in a specific area of the country than if they are asked to display solidarity with the population at large. In the event, contributions from the formal sector do not seem to be automatically easier to collect than other taxes. In urban China, only $24 \%$ of private sector employees and $50 \%$ of state-owned enterprise employees are enrolled in the new urban health insurance scheme (Chen 2004; Wu 2004). In Vietnam, for every formal sector worker enrolled in SHI, there are two who are not enrolled (Nguyen 2006). In addition to nonenrollment, evasion is also a problem in countries where people can fall back on subsidized health ministry facilities if they do not enroll in the SHI scheme. In Colombia, evasion in the contributory regime (which covers formal sector workers as well as informal workers not classified as poor) evasion has been identified as one of the most pressing problems facing the 
health sector, amounting to US\$836 million in 2000, equivalent to 2.75\% of GDP (Escobar and Panopolou 2003). Nearly three-quarters of this was due to underreporting, the rest being due to nonpayment. Contrary to expectations, the introduction SHI schemes in eastern Europe and the former Soviet Union have not actually resulted in additional revenues for health care, not least because of problems in collecting revenues; in Kazakhstan, for example, only $40 \%$ of expected revenues were actually collected (Gottret and Schieber 2006). By contrast, some taxes—indirect taxes, for example—are relatively hard to evade, and relatively cheap to collect. Collection costs in SHI systems, by contrast, are nontrivial; and, of course, given that taxes have to be collected for other purposes anyway, and there are economies of scale in tax collection, the collection costs associated with SHI could probably by and large be avoided altogether if health care were financed out of general revenues.

The idea that governments cannot increase general revenues to increase spending in a tax-financed system but can introduce social insurance contributions (i.e. payroll taxes) is also one that merits examination. On the face of it, it seems odd. If people are paying large sums outof-pocket for their health care, basic economics suggests they would prefer to convert these uncertain payments into a certain 'premium', which could take the form of a social insurance contribution or additional taxes. One reason the former might be preferred is that people do not trust the government to spend the extra taxes on health, or they do not trust the existing health system to deliver quality care with the extra resources. But that begs many questions. How much of the insurance contribution revenues would get eaten up by the administrative costs associated with setting up and running a SHI system? Would the SHI system do any better at converting revenues into quality care? And might not the very governance issues that make citizens suspicious of their government not also make the government a weak regulator of a SHI scheme? Perhaps a more likely reason is that higher income groups feel frustrated by the limited services 
offered through the tax-financed program but would prefer SHI over a fee-paying private sector or private insurance, assuming their SHI contributions translate into better quality care and lower out-of-pocket payments for them. A hidden agenda, therefore, might well be that introducing SHI in a tax-financed system offers the chance of introducing a parallel delivery system for the better off (or at least the prospect of better care at lower cost), along the lines of the systems of Latin America. It is worth considering whether this is the best option for catering to what might reasonably be argued to be the legitimate demands of the better off.

Taxes are often discussed as if they are a fixture, and independent of the existence and scale of any SHI scheme. Neither is likely to be the case. Embarking down the SHI road is likely to take the pressure off the finance ministry to raise tax revenues for health. There is a risk that the difficulties of achieving UHI through SHI become apparent only after years of trying, by which time, the finance ministry will have come to think of the health system as a contributory one not needing tax-financed subsidies. By contrast, if the health ministry is engaged with the ministry of finance (especially if it has a clear mechanism for containing costs and delivering quality care and sets and hits performance targets), it is not inconceivable that a case for extra resources could successfully be made.

This might necessitate additional tax revenues. But a country's tax revenue is not a fixture. Many developing countries have unnecessarily narrow tax bases. China's VAT, for example, does not apply to services, and its real estate taxes are defined on a base that is narrower than need be (Ahmad 2006). Tax bases can be widened through reform, and rates can be modified. Such reforms offer the prospect of higher revenues, some of which can be-and have been—used to expand government health financing. Bolivia, for example, through a major tax reform raised tax revenues from 3\% of GDP in 1983 to 17\% by the end of 1987 (Wagstaff 
and Claeson 2004). It replaced a highly complex tax system containing more than 100 taxes (differential import tariffs, earmarked taxes, progressive personal income taxes, and corporate taxes with many exceptions and loopholes) with a simple structure of six taxes. ${ }^{6}$ The health sector in Bolivia has benefited from this growth of tax revenues: government health spending as a share of GDP grew at an annual rate of nearly 10\% during the 1990s. A recent World Bank report (World Bank 2006) lists other countries, including Armenia, Bulgaria, Estonia, Kazakhstan, Russia and Slovakia, that have reformed taxes paid by businesses (including payroll taxes and VAT) and in the process have increased tax revenues. Measures adopted include: simplifying taxes, limiting incentives and exemptions, as well as reducing tax rates; such measures tend to encourage tax compliance and also prevent pushing businesses into the informal economy.

SHI revenues sometimes do exhibit less year-to-year variation than government spending on health (cf. e.g. Nonneman and van Doorslaer 1994). But SHI systems are not immune to financial crises, which can occur in both downturns and upswings. Germany’s current health care crisis has occurred partly because SHI revenues fell as unemployment rose (the contributions paid by Germany’s workers also pay for cover for the unemployed) and as the population grew older. By contrast, Taiwan’s social insurance system experienced a financial crisis during a period of rapid economic growth, because contributions were capped and contribution rates were not uprated in line with growth of per capita income. Only after a fierce political debate were contributions increased (Lu and Hsiao 2003). In any case, it is not clear that having resources flow automatically into a SHI fund is necessarily a good thing, and that having a tax-financed

\footnotetext{
${ }^{6}$ These included: a 10\% VAT on a broad base, excluding only housing and financial services; taxes on consumption of luxury goods (alcoholic beverages, perfumes, cosmetics, tobacco, and jewelry); a 1\% transaction tax (a cumulative turnover tax); a progressive tax on vehicles (1.5\%-5\%) and urban real estate (1.5\%-3\%); a $2 \%$ tax (increased to $2.5 \%$ in 1988 ) on the net worth of public and private enterprises (small informal enterprises paid a fixed lump sum instead); and a uniform import tariff rate of 20\% (reduced to 10\% in 1988). All other taxes were eliminated, including personal and corporate income taxes.
} 
budget being "vulnerable" to the outcomes of government-wide negotiations-the "whimsical nature of governments” as two commentators (Nonneman and van Doorslaer 1994) put it—is necessarily a bad thing. The merit of the latter arrangement is that it permits a more open debate about public spending tradeoffs between health and other sectors, and provides a clear way for those managing government spending on health to be held accountable. Such debates tend to happen less in a SHI system except insofar as the SHI agency has to appeal, as in Taiwan, for modifications to contribution schedules to cover losses. Part of Germany's concern, for example, is that resources have continued to flow into SHI, and the costliness of care has risen accordingly, so much so that Germany's share of GDP devoted to health care is third highest in the OECD. Had the Germans had a continuous political debate about the tradeoffs between health and other sectors, they might have made ended up devoting a smaller share of GDP to health. In the Philippines, the SHI agency started facing tough questioning from Congress on its financial plans only after its tax-financed indigent program was introduced.

Equity in the way revenues are raised also matters. Payroll contributions are often regressive, due to contribution ceilings; by contrast, general revenues are typically proportional if not progressive (Wagstaff et al. 1992; Wagstaff et al. 1999; O'Donnell et al. 2005). In a lowincome setting, where poorer households grow much of their own food, and luxury goods are taxed at higher rates, even indirect taxes can be progressive; direct taxes often are too, because they are paid only by the formal sector. It is not just progressivity—or vertical equity—that matters: horizontal equity matters too. In a SHI system, it is common for people in different schemes to end up paying different amounts for essentially the same benefit package, because they are locked into specific schemes for reasons of occupation or geography, and the government's equalization scheme does not achieve full (horizontal) equality (Van Doorslaer et al. 1999; Wagstaff 2006). 


\section{What of the informal sector?}

The core concept of SHI is that wage-earners make mandatory contributions based on their wages, with the employer and employee sharing the cost. In the developing world today, a large — and increasing (Gottret and Schieber 2006)_fraction of the population (sometimes the majority) is not employed in the formal sector. In Latin America, where SHI has the longest history in the developing world, a parallel tax-financed system, with separate facilities operated by the health ministry, has been maintained to cater for the informal sector. These facilities have had fewer resources and are argued by some to deliver poorer quality and more limited care. The cost of care at the point of use is typically higher for those not enrolled in the SHI scheme, either because they are liable for copayments or because the benefit package is limited and they end up paying out-of-pocket for care not included in it. It is scarcely surprising, therefore, that Xu et al (2003) find a high incidence of catastrophic household health spending in several (though not all) Latin American countries (notably Argentina, Brazil, Colombia, Paraguay, and Peru), and why SHI membership is associated in some countries, such as Vietnam (Jowett, Contoyannis and Vinh 2003), with dramatically lower household out-of-pocket spending.

Unsurprisingly, therefore, efforts have been made to bring informal sector workers and their families under the SHI umbrella, the goal being to ensure universal and equal coverage. Many countries have succeeded in setting up a scheme for poor, financing their SHI membership out of general revenues. Most, however, typically commit large errors of exclusion, largely because poor households fail to apply. In Colombia in 2003 (ten years after the reform), less than $50 \%$ of the principal target group (households in categories 1 and 2 of the 'SISBEN' meanstesting instrument) is actually enrolled in the non-contributory scheme (Gaviria, Medina and Mejía 2006). In Vietnam, about $40 \%$ of those who ought to have received health insurance 
coverage (or a free health care card) by virtue of being poor actually had done so in 2004 (Wagstaff 2007). Errors of inclusion are also common. In Colombia, over one quarter of households in SISBEN category 4 are enrolled in the non-contributory (subsidized) program but ought not to be covered under the rules (only categories 1 and 2 are universally covered; some municipalities also cover some households in SISBEN category 3) (Gaviria, Medina and Mejía 2006). In Mexico, only $43 \%$ of those covered at the taxpayer's expense in Seguro Popular ${ }^{7}$ are actually in the poorest $20 \%$ of the population — the official cutoff point (Scott 2006).

Enrolling nonpoor informal sector workers and their families in SHI has proved even harder. This undoubtedly reflects the lack of attractiveness of the terms on which informal sector households enroll. Often the contribution is flat-rate, and therefore represents a burden for the near-poor. The enrolled often end up using the same public facilities they would use if they were not enrolled, and while they may end up with lower out-of-pocket payments, they typically do not fall to zero upon enrollment. Furthermore, people who do not enroll typically pay a price in public facilities that is subsidized, often heavily so. In many countries, people would probably prefer to use private providers, including drug vendors, and these are typically not covered by the scheme. People perceive the drugs that are covered by the insurance scheme as lower quality than those they can purchase_-often without a prescription—at a pharmacy. And finally, in some countries, informal payments are rife, and these are also not covered; in fact, the providers may expect more generous informal payments of the insured, using insurance status as a signal of ability to pay.

Vietnam is one of the many countries where many-if not all_of these factors help explain why voluntary SHI enrollment among informal sector workers and the families of formal

\footnotetext{
${ }^{7}$ Seguro Popular is the health ministry's semi-SHI scheme that operates in parallel to the social security institute's SHI scheme, and is aimed at the informal sector. The poorest two deciles are exempt from contributions. The remainder of the population contributes according to assessed income.
} 
sector workers has got stuck at around 20\% of the target group (Nguyen 2006). As much as 13 percentage points of this is due to enrollment by schoolchildren, who are enrolled en bloc with a good deal of arm-twisting by the authorities. In the Philippines, only $14 \%$ of the target group is voluntarily enrolled with PhilHealth, ten years after its inception (Nguyen 2006). In Colombia, where enrolment by nonpoor informal sector workers is compulsory, enrolment in the contributory scheme among the richest $60 \%$ of the population-including formal sector workers - is only 52\%, ten years after the reform that made insurance compulsory for nonpoor informal sector workers (Tono 2006). In Tanzania, total enrollment in the new SHI scheme is just 3\% of the population, five years after the scheme's establishment (Nguyen 2006). In the Kyrgyz Republic, attempts to enroll the informal sector have largely failed. In Ghana, one year after the scheme's start, enrollment stood at $21 \%$ of the population, but only 5 percentage points of the 21 represented enrollment by contributing informal sector workers. Efforts in some countries are being made to enroll the informal sector through group associations (e.g. microcredit organizations), but the progress is painfully slow. One developing country that has succeeded—at least for the moment—where others so far have failed is China, where enrollment in its new subsidized and voluntary rural health insurance scheme is around $80 \%$ in pilot counties (Wagstaff et al. 2007). However, such high enrollment rates appear to have been the result of pressure being exerted by local government officials eager to hit their enrollment targets; some have been so keen in fact that they have waived the household's contribution and have financed it out of local government revenues. And coverage is so shallow that insured households still pay the vast majority of health care costs out-of-pocket. The sustainability of such an approach even in China seems questionable, and it is one that is ill suited to the most other developing countries. 
Where people are enrolling in SHI schemes, there is some evidence that it is the worst risks that are enrolling. Such adverse selection appears to exist in the Philippines, for example, and is argued to pose challenges for the financial sustainability of PhilHealth (Jowett 2006). It appears to be present in China's rural scheme (Wagstaff et al. 2007). It would, in fact, be surprising if it wasn't a problem in all schemes that are voluntary in nature if not in name, given the evidence on the subject from the around the world.

Furthermore, among informal sector workers who do enroll the contributions forthcoming are often less than they ought to have been, according to the contribution rules. In the Philippines, where contributions by individual paying members are flat-rate, only $75 \%$ of revenues have actually been collected (Obermann et al. 2006). In Mexico's Seguro Popular program, where contributions are linked to assessed income, only $8 \%$ of enrollees in the richest $60 \%$ of the population actually contributed (all should have done so according to the rules), and those who did contributed on average less than half of what they ought to have done (Scott 2006). And, as has already been noted, the costs associated with collecting these less-thanexpected contributions are often considerable.

The difficulties that developing countries today are experiencing in extending coverage to nonpoor informal sector workers and in raising contributions from them point towards a long and frustrating road to universal coverage under SHI. The European SHI countries studied by Carrin and James (2004) (Austria, Belgium, Germany and Luxembourg) took close to 100 years to achieve universal health insurance (UHI). Costa Rica, Japan and Korea, which achieved UHI in 1991, 1958 and 1989 respectively took considerably less time, though Costa Rica's coverage rate in 1991 was still only 85\%, and Japan and Korea were both at an advanced stage of economic development when they reached UHI (Japan’s per capita income was \$7876 in 1961 in 2000 
prices, while Korea’s was $\$ 6133$ in 1989) (Carrin and James 2004; Wagstaff 2006). In the early 1980s, when Korea was extending coverage to the informal sector, it experienced similar problems collecting contributions to those being experienced now by developing countries: the health insurance societies had difficulty identifying the income level of informal sector workers, collecting the payment and determining the number of family members (there was an incentive for people to declare others as family members to receive benefits without paying); they also faced the problem that some households were genuinely unable to pay their contributions (Anderson 1989). Even today, the Korean government subsidizes about half of the contribution of the self-employed. In Japan, the role of tax finance is even larger: nearly $20 \%$ of total health spending compared to Korea’s 10\% (O'Donnell et al. 2005).

Clearly, the chances of SHI leading to universal coverage in economies containing large numbers of informal sector workers are slim: the bigger the informal sector, the bigger the likely coverage gap. In such economies, SHI would not seem an especially promising route to achieving universal coverage, whether for a package that contains just 'basic' cost-effective interventions, or for one that contains these plus a few 'catastrophic' interventions. This conclusion helps explain why Thailand, which is strongly committed to UHI, relies on payroll contributions for only $12 \%$ of its population (those working in private businesses), and covers most of the rest of the population through taxation. ${ }^{8}$ It also explains why China is contemplating using tax revenues to finance a universal package of 'basic' services.

\footnotetext{
${ }^{8}$ In 2002, the government increased coverage from $80 \%$ to $96 \%$ by introducing a tax-financed scheme with a small (30-baht) copayment for those previously uncovered (13\% of the population), and all those previously covered at the taxpayer's expense apart from current and retired civil servants and their dependents (61\% of the population).
} 


\section{SHI, unemployment and the informalization of the economy}

Important as the aforementioned issues are, they are not the ones that have dominated the recent health reform debate in the oldest of SHI countries-Germany. Rather the issue is the perceived impact of SHI contributions (currently around 14\% of earnings) on the nonwage component of labor costs, which are argued to have reduced the competitiveness of German firms abroad, discouraged foreign investment in German industry, and contributed to the high level of unemployment. It is because of these perceived negative effects that the German health minister described the exclusive linking of health finance to earnings rather than income more generally as “the Achilles heel” of the German's social insurance system (Schmidt 2006). Both of the main political parties in Germany are, in fact, committed to changing the way health care is financed, the Social Democrats favoring households paying contributions linked to income from all sources, and the Christian Democrats favoring a flat-rate contribution with subsidies for low-income households (Schmidt 2006). A compromise has been proposed—but not yet agreed upon among the coalition partners (Der Spiegel 2006)—in which contributions would be reduced and channeled into a central health fund, which would be financed in part by taxes (to generate the necessary additional tax revenues, tax liabilities would rise by $8 \%$, or equivalently income tax would increase by three percentage points) (International Network on Health Policy \& Reform 2006).

The idea that a heavy emphasis on payroll taxes in financing of health care has negative consequences for employment is consistent with the OECD's Job Strategy recommendations to its members to lower payroll taxes (OECD 1999). It is not, however, uncontroversial. Because payroll taxes finance a program whose benefits accrue to the payers of the taxes, the effect on employment may in practice be muted. This is because, as Summers (1989) has argued, the 
payroll tax induces not only a leftwards shift of the labor demand curve, but also a rightwards shift in the labor supply curve (worker's value the benefits they receive that are financed through the tax, and are hence willing to supply more labor at a given money wage), producing a smaller disemployment effect than in the standard case and a larger reduction in the post-tax wage. Empirical evidence on the impact of payroll taxes on wages and employment is mixed. In Colombia, the health reforms of the 1990s raised the payroll tax rate by 5 percentage points; these, according to a recent study of Colombia’s payroll tax incidence (Kugler and Kugler 2003), would have reduced wages by between $0.7 \%$ and $1.1 \%$, and employment by between $2 \%$ and 2.5\%. By contrast, Bauer and Riphahn (2002) find that Germany's payroll tax has had very limited employment effects.

The effects of payroll taxes on employment are, in any case, only one part of the story. If payroll taxes were used less, other taxes would have to be used more. The issue at stake is whether other taxes would have smaller impacts on employment. Raising the income tax would reduce the returns to work and would hence shift the labor supply curve leftwards, also causing a reduction in employment. A rise in indirect taxes would reduce real wages, reducing people's willingness to work at a given nominal wage, again potentially reducing employment. In both cases, one could argue that insofar as revenues are used to finance programs that benefit the payers of the taxes, the labor supply curve might shift rightwards, along the lines argued by Summers for the payroll tax; this would moderate the disemployment effect. However, it seems likely that because the linkage between taxes paid and the benefits of the health insurance program are likely to be perceived as less close in the case where revenues are raised through the income tax and indirect taxes than in the case where they are raised through a payroll tax, the rightwards shift in the labor supply curve is likely to be much smaller in the former case than the latter case, and may be imperceptible. It is not inconceivable, therefore, that the disemployment 
effect of a payroll tax may actually be less than that associated with income taxes and indirect taxes.

In practice, it seems that, at least as far as the OECD countries are concerned, payroll, income and consumption taxes all have broadly similar effects on employment (cf. Nickell 2004; Nickell, Nunziata and Ochel 2005). Denmark, for example, which has no payroll tax, has until recently had similar unemployment rates to other European countries (Nickell 1997). As Nickell (1997) puts it, "Broadly speaking, the key tax rate for the labor market is the sum of the payroll tax rate, the personal income tax rate and the consumption tax rate. Switching between these taxes will not have an important impact, so payroll taxes, per se, are of little consequence.” (p.68). How far this argument applies when other forms of government revenue are taken into account is less clear. It seems likely that some other taxes—such as import duties—may have much smaller effects on employment, in which case shifting from payroll taxes to general revenues more broadly may help lower unemployment.

What does seem certain, however, is that SHI can provide a disincentive for people to join and stay in formal employment; SHI may thus not raise unemployment, but it may raise the fraction of people in employment who are working in the informal sector. This issue has received attention in Latin America as well as in Europe (Belev 2003; Baeza and Packard 2006; Datta 2006). The incentive is likely to be especially large in the case where enrollment in the SHI scheme is voluntary or only weakly enforced among informal sector workers (which is the norm), so that people may opt for informal employment arrangements and run the risk of facing a higher (though subsidized) price in the health ministry's public system or are required to (or may) take out private insurance. In countries where informal workers pay a flat-rate contribution (Vietnam for example), or where contributions are supposed to be linked to income but in 
practice may only be weakly linked (Mexico's Seguro Popular scheme, for example), some workers will find that by opting for informal employment arrangements they can keep their insurance coverage (albeit possibly with somewhat less generous coverage) and pay a substantially lower contribution. In Germany, the self-employed are required to take out private insurance or join the SHI scheme, but typically elect for the former, because the private insurance is often cheaper than SHI, especially for people who do not have dependents and who take out private insurance when they are young (once insured, the premium remains that set for the person's age cohort when the person joined—they rise only according to increases in overall health care costs). These incentives become even more of an issue if being in formal employment means being drawn into the tax system and having to contribute to a pension scheme that because of limited life expectancy may only pay out for a few years if any. SHI thus contributes potentially to growing informality of the economy, with all the negative connotations, including a reduction in the government's ability to raise taxes. This is one of the reasons why a recent book on health systems in Latin America recommended a gradual move from payroll financing to general revenue financing (Baeza and Packard 2006).

It is not just on the formal-informal margin that SHI creates perverse incentives. Especially if free SHI membership for the poor is bundled with other safety net benefits, the poor will face a poverty trap-earning a little more could result in loss of SHI membership (perhaps for the entire household), as well as other bundled benefits. Evidence from Colombia (Gaviria, Medina and Mejía 2006) suggests that being in the subsidized SHI program reduces female labor force participation by 34 percentage points. SHI may thus at once contribute to the government's anti-poverty efforts by providing insurance to the poor, but may also undermine them by reducing people’s incentives to escape poverty. 


\section{Summary and discussion}

SHI is simply a way of financing health care. It is not always associated with a purchaserprovider split, but can be. So too, however, can a tax-financed health system. Increasingly, in fact, such splits are seen in tax-financed systems. There is no compelling evidence that SHI purchasers are more effective than tax-financed purchasers; in fact, there are some who argue the opposite. Nor is it clear that SHI provides an effective way of raising revenues that are larger and more predictable. The payroll tax base (the earnings of those in the formal sector) is small in developing countries, and nonenrollment is commonplace, as is underreporting of earnings and evasion by those enrolled. Partly because of this and partly because taxes need to be collected anyway and the marginal cost of raising additional taxes is likely to be low, the collection costs in a SHI system are likely to be substantially higher than in a tax-financed system. Raising additional taxes is, of course, not straightforward. But it is not impossible, as the tax reforms in several developing countries have shown. Taking health finance out of the finance ministry's remit may also lessen the pressure for tax reform: it could well mean forgoing opportunities for tax reform that could lead to sustainable levels of health finance with universal coverage. The governance of SHI agencies in the developing world often leaves something to be desired, resulting in high costs and poor purchasing practices. Competition is argued by some to be a way of improving accountability to members, but is associated with its own problems, including risk selection. Arguably, however, the main challenge of SHI is the informal sector. Buying coverage for the poor through tax finance is relatively easy, though errors of exclusion and inclusion are commonplace. Much tougher is the challenge of covering nonpoor informal sector workers whose share in the population is growing rather than falling; countries that have successfully brought them into the SHI scheme have typically only done so only at a fairly advanced stage of economic development. SHI also faces challenges vis-à-vis employment and poverty reduction. 
It is thought to contribute to unemployment, though in the OECD countries it is far from clear that it is worse than income and indirect taxes in this respect, and to encourage the informalization of the economy by giving workers an incentive to leave formal sector employment. Schemes to cover the poor also give households a disincentive to increase their incomes.

SHI is thus far from the panacea it is often portrayed to be. Tax-financing is, of course, not without its problems. One area where it is vulnerable is the homogeneity of care: it fails to provide a mechanism for responding to the demands by the better off for more sophisticated health care or better amenities, and forces everyone down to the same standard. One way-and a bad way_ of responding to this challenge is to allow the better off and the politically connected access to expensive care at the tax-payer's expense in facilities that are inaccessible to the bulk of the rest of the population (i.e. urban hospitals). This happens in Africa and probably explains the pro-rich government spending distributions there (Castro-Leal et al. 2000). It also happens in some of the Former Soviet Union countries. This approach almost certainly entails a far higher rate of "leakage" of government funds to the nonpoor than is required to retain their political support for a tax-financed system. An arguably better model is one where providers receive payments from government that keep in check the sophistication of health care and the amenities of the facilities in which it is delivered, and forces the better off who want to obtain more sophisticated care or better amenities into the private sector. Inequalities in use of services will still be evident, but they will be lower than they would otherwise have been. This is basically the model operated by countries like Brazil, Britain, Ireland, Malaysia, Sri Lanka, and Sweden, where the private sector operates as a limited safety valve. 
There are, of course, other challenges that tax-financed systems face, including the challenge of introducing a purchaser-provider split and giving providers an appropriate degree of autonomy. But these are not insuperable. And a tax-financed system has the three great merits of not leaving a large portion of the population with inferior insurance coverage while the health system staggers slowly down the long road to universal coverage, avoiding many of the labor market distortions associated with payroll financing, and raising revenues in an equitable fashion. These are important plusses, the first especially so for developing and transition economies. But as recent developments in the old SHI countries show, they remain important considerations even at advanced stages of economic development. 


\section{References}

Ahmad, E. (2006). Taxation reforms and sequencing of intergovernmental reforms in China-preconditions for a xiaokang society. Washington DC, World Bank, Mimeo.

Anderson, G. F. (1989). "Universal health care coverage in Korea." Health Aff (Millwood) 8(2): 24-34.

Baeza, C. and T. Packard (2006). Beyond Survival: Protecting Households from Health Shocks in Latin America. Washington, DC, World Bank.

Bauer, T. and R. T. Riphahn (2002). "Employment Effects of Payroll Taxes--An Empirical Test for Germany." Applied Economics 34(7): 865-76.

Belev, B., Ed. (2003). The Informal Economy in the EU Accession Countries: Size, Scope, Trends and Challenges o the Process of EU Enlargement. Sofia, Center for the Study of Democracy.

Bhushan, I., S. Keller and B. Schwartz (2002). Achieving the twin objectives of efficiency and equity: Contracting health services in Cambodia. Manila, Asian Development Bank, ERD Policy Brief Series \#6.

Carrin, G. and C. James (2004). Reaching universal coverage via social health insurance. Geneva, WHO, Health System Financing, Expenditure and Resource Allocation Discussion Paper \#2.

Castro-Leal, F., J. Dayton, L. Demery and K. Mehra (2000). "Public spending on health care in Africa: do the poor benefit?" Bulletin of the World Health Organization 78(1): 66-74.

Chen, J. (2004). "A Ten-year review and prospects of Chinese medical insurance system." China Medical Insurance Research(3): 6-8.

Datta, S. (2006). Is Germany gearing up for health care reform?, Frost \& Sullivan.

Der Spiegel (2006). A Sickly Compromise for German Healthcare Reform. SPIEGEL ONLINE.

Docteur, E. and H. Oxley (2003). Health care systems: Lessons from the reform experience. Paris, OECD, OECD Health Working Papers 9.

Escobar, M.-L. and P. Panopolou (2003). Health. Colombia : the economic foundation of peace. M. Giugale, O. Lafourcade and C. Luff. Washington, DC, World Bank: 653-707.

Fiedler, J. L. (1996). "The privatization of health care in three Latin American social security systems." Health Policy Plan 11(4): 406-17. 
Gaviria, A., C. Medina and C. Mejía (2006). Evaluating The Impact Of Health Care Reform In Colombia: From Theory To Practice. Bogota, Universidad de Los Andes-CEDE, Documentos CEDE 002682.

Gottret, P. E. and G. Schieber (2006). Health financing revisited : a practitioner's guide. Washington, DC, World Bank.

International Network on Health Policy \& Reform (2006). Health Policy Monitor, Bertelsmann Stiftung, Gütersloh.

Jonsson, B. and P. Musgrove (1997). Government financing of health care. Innovations in health care financing : proceedings of a World Bank conference, March 10-11, 1997. G. Schieber. Washington, DC, World Bank: vii, 255.

Jowett, M. (2006). Group enrolment into SHI in the Philippines: the conceptual framework. Manila, Presentation at Conference on Extending Social Health Insurance to Informal Economy Workers Manila, Philippines 18th - 20th October 2006.

Jowett, M., P. Contoyannis and N. D. Vinh (2003). "The impact of public voluntary health insurance on private health expenditures in Vietnam." Soc Sci Med 56(2): 333-42.

Kenkel, D. S. (2000). Prevention. Handbook of health economics. A. J. Culyer and J. P. Newhouse. Amsterdam ; New York, Elsevier: 2 v.

Kugler, A. and M. Kugler (2003). The Labour Market Effects of Payroll Taxes in a MiddleIncome Country: Evidence from Colombia, C.E.P.R. Discussion Papers, CEPR Discussion Papers: 4046.

Lewis, M., G. Eskeland and X. Traa-Valerezo (2004). "Primary health care in practice: is it effective?" Health Policy 70(3): 303-25.

Lu, J. R. and W. C. Hsiao (2003). "Does Universal Insurance Make Health Care Unaffordable? Lessons from Taiwan." Health Affairs 22(3 (May/June 2003)): 77-88.

Micheli, A., J. W. Coebergh, E. Mugno, E. Massimiliani, M. Sant, W. Oberaigner, J. Holub, H. H. Storm, D. Forman, M. Quinn, T. Aareleid, R. Sankila, T. Hakulinen, J. Faivre, H. Ziegler, L. Tryggvadottir, R. Zanetti, M. Dalmas, O. Visser, F. Langmark, M. BielskaLasota, Z. Wronkowski, P. S. Pinheiro, D. H. Brewster, I. Plesko, V. Pompe-Kirn, C. Martinez-Garcia, L. Barlow, T. Moller, J. M. Lutz, M. Andre and J. A. Steward (2003). "European health systems and cancer care." Ann Oncol 14 Suppl 5: v41-60.

Nguyen, T. K. P. (2006). Extending Social Health Insurance to Informal Economy Workers The Case of Vietnam. Manila, Presentation at Conference on Extending Social Health Insurance to Informal Economy Workers Manila, Philippines 18th - 20th October 2006.

Nickell, S. (1997). "Unemployment and Labor Market Rigidities: Europe versus North America." Journal of Economic Perspectives 11(3): 55-74. 
Nickell, S. (2004). Employment and Taxes, Centre for Economic Performance, LSE, CEP Discussion Papers.

Nickell, S., L. Nunziata and W. Ochel (2005). "Unemployment in the OECD Since the 1960s: What Do We Know?" Economic Journal 115(500): 1-27.

Nonneman, W. and E. van Doorslaer (1994). "The role of the sickness funds in the Belgian health care market." Soc Sci Med 39(10): 1483-95.

Obermann, K., M. R. Jowett, M. O. Alcantara, E. P. Banzon and C. Bodart (2006). "Social health insurance in a developing country: the case of the Philippines." Soc Sci Med 62(12): 3177-85.

O'Donnell, O., E. Van Doorslaer, R. Rannan-Eliya, A. Somanathan, S. R. Adhikari, B. Akkazieva, D. Harbianto, C. G. Garg, P. Hanvoravongchai, A. N. Herrin, M. N. Huq, S. Ibragimova, A. Karan, S.-M. Kwon, G. M. Leung, J.-F. R. Lu, Y. Ohkusa, B. R. Pande, R. Racelis, K. Tin, L. Trisnantoro, C. Vasavid, Q. Wan, B.-M. Yang and Y. Zhao (2005). Who pays for health care in Asia? EQUITAP Working Paper \# 1, Erasmus University, Rotterdam and IPS, Colombo.

OECD (1999). The OECD Jobs Strategy Implementing the OECD Jobs Strategy: Assessing Performance and Policy. Paris, OECD.

Reinikka, R. and J. Svensson (2003). Working for God? Evaluating Service Delivery of Religious Not-for-Profit Health Care Providers in Uganda. Washington DC, World Bank, Policy Research Working Paper Series \#3058.

Schmidt, U. (2006). Health policy and health economics in Germany. Washington DC, Friedrich Ebert Foundation, Speech.

Scott, J. (2006). Seguro Popular Incidence Analysis. Decentralized Service Delivery for the Poor Vol. II. World Bank. Washington DC, World Bank.

Summers, L. H. (1989). "Some Simple Economics of Mandated Benefits." American Economic Review 79(2): 177-83.

Tono, T. (2006). Director Health Care Reform Ministry of Social Protection Colombia.

Van Doorslaer, E., A. Wagstaff, H. van der Berg, T. Christiansen, G. Citoni, R. Di Biase, U. Gerdtham, M. Gerfin, L. Gross, U. Häkkinen and J. John (1999). "The redistributive effect of health care finance in twelve OECD countries." Journal of Health Economics 18(3): 291-314.

Wagstaff, A. (2006). "Health Systems in East Asia: What Can Developing Countries Learn From Japan and the Asian Tigers?" Health Economics in press.

Wagstaff, A. (2007). Health Insurance for the Underprivileged: Initial Impacts of Vietnam's Health Care Fund for the Poor. Washington DC, World Bank, Mimeo. 
Wagstaff, A. and M. Claeson (2004). The Millennium Development Goals for Health, Rising to the Challenges. Washington DC, World Bank.

Wagstaff, A., M. Lindelow, J. Gao, L. Xu and J. Qian (2007). Extending Health Insurance to the Informal Sector: An Impact Evaluation of China's New Cooperative Medical Scheme. Washington DC, World Bank, Mimeo.

Wagstaff, A., E. van Doorslaer, S. Calonge, T. Christiansen, M. Gerfin, P. Gottschalk, R. Janssen, C. Lachaud, R. E. Leu, B. Nolan and et al. (1992). "Equity in the finance of health care: some international comparisons." J Health Econ 11(4): 361-87.

Wagstaff, A., E. van Doorslaer, H. van der Burg, S. Calonge, T. Christiansen, G. Citoni, U. G. Gerdtham, M. Gerfin, L. Gross, U. Hakinnen, P. Johnson, J. John, J. Klavus, C. Lachaud, J. Lauritsen, R. Leu, B. Nolan, E. Peran, J. Pereira, C. Propper, F. Puffer, L. Rochaix, M. Rodriguez, M. Schellhorn, O. Winkelhake and et al. (1999). "Equity in the finance of health care: some further international comparisons." J Health Econ 18(3): 263-90.

World Bank (1997). Argentina: Facing the Challenge of Health Insurance Reform. Washington DC, World Bank, Report No. 16402-AR.

World Bank (2006). Paying Taxes: The Global Picture. Washington DC, World Bank

Wu, R. (2004). "Try to perfect the system." China Medical Insurance Research 1,2: 16-19.

Xu, K., D. B. Evans, K. Kawabata, R. Zeramdini, J. Klavus and C. J. Murray (2003). "Household catastrophic health expenditure: a multicountry analysis." Lancet 362(9378): 111-7. 